DOI 10.37882/2223-2982.2021.02-2.27

\title{
НРАВСТВЕННЫЕ «КОНЦЕПТЫ» В ТРАГЕДИИ У. ШЕКСПИРА «МАКБЕТ»
}

\section{MORAL "CONCEPTS» IN THE TRAGEDY BY W. SHAKESPEARE «MACBETH»}

\section{Ya. Pirogova}

Summary: The study analyzes the concept of "concept» and considers different views on the issue of linguists. The article makes an attempt to analyze the "concept» of exposure, expressed through the concepts of «friendship», «military honor», «valor», «evil», «lie», «pretense», «betrayal» in the tragedy of W. Shakespeare «Macbeth».

Keywords: concept, exposure, epithet.

\section{Постановка проблемы}

$\mathrm{B}$ современном мире термин «концепт» употребляется в различных гуманитарных областях знания, в частности в культурологии и лингвистике, и имеет вариативность определения. Как и любой термин концепт может рассматриваться как в узком, так и в широком смысле, и каждый ученый вкладывает свое понимание и разрабатывает свою дефиницию для этого термина.

\section{Анализ послеАних исслеАований и публикаший}

С.А. Аскольдов в своей статье «Концепт и слово» предлагает под концептом понимать «мысленное образование, которое замещает нам в процессе мысли неопределенное множество предметов одного и того же рода» [2].

По Ю.С. Степанову «концептом» является «некое суммарное явление, по своей структуре состоящее из самого понятия и ценностного (нередко образного) представления о нем самого человека»[1].

Е.С. Кубрякова, С.Х. Ляпина и О.П. Скидан подразумевают под «концептом» «многомерный мыслительный конструкт, отражающий процесс познания мира, результаты человеческой деятельности, его опыт и знания о мире, хранящий информацию о нем»[1].

По мнению ряда ученых»понятийная сторона концепта - это то, как концепт зафиксирован на языке, его обозначение, описание, признаковая структура, дефиниция, сопоставительные характеристики данного концепта по отношению к другим концептам»[6].

Ввиду наличия в становлении концептов конкретных

\author{
Пирогова Яна Владимировна \\ Оренбургский государственный университет \\ yana_pirogova24@mail.ru
}

Аннотация: В исследовании проанализирована сущность понятия «концепт» и рассмотрены разные взгляды на вопрос лингвистов. Предпринята попытка анализа концепта «изобличения», актуализированного через понятия «дружба», «воинская честь», «доблесть», «зло», «ложь», «притворство», «предательство» в трагедии У. Шекспира «Макбет».

Ключевые слова: концепт, изобличение, эпитет.

исторических условий и отражения в концептах национальной специфики и культурного контекста, я бы хотела остановиться на трактовке концепта, выведенного И. С.Шулятиковым: «концепт» — «единица коллективного сознания, отправляющаяся к высшим духовным ценностям, имеющая языковое выражение и отмеченная этнокультурной спецификой»[7].

Хотелось бы остановиться на трагедии У. Шекспира «Макбет», дабы рассмотреть как концепты актуализируются в этом произведении. Стоит сказать об обилии средств речевой выразительности в шекспировских произведениях: метафоры, эпитеты, олицетворения, сравнения, и остановиться на эпитетах как на одних из основных художественных средств У. Шекспира.

Стоит отметить, что эпитет не имеет однозначного, четко фиксированного определения, однако часто несет субъективное восприятие автора и его эмоциональную окраску.

Ю.М. Скребнев понимает под эпитетом «слово или словосочетание, содержащие экспрессивную характеристику предмета речи, прилагаемую к наименованию последнего»[4]. Н.Г. Гольцова и И.В. Шахмин рассматривают эпитет как «определение, подчеркивающее характерное свойство предмета, а также придающее ему поэтическую яркость, художественную выразительность, образность»[5; с. 63].По И.Р. Гальперину, эпитет- «выразительное средство, основанное на выделении качества, признака описываемого явления, которое оформляется в виде атрибутивных слов или словосочетаний, характеризующих данное явление с точки зрения индивидуального восприятия этого явления»[3; с. 139]. 
В своих творениях У. Шекспир поднимает вопросы человеческой природы, вследствие чего в его работах, в частности в трагедии «Макбет», много абстрактных нравственных концептов: концепты «дружба», «воинская честь», «доблесть»; концепты «зло», «ложь», «притворство», «предательство», которые объективируются посредством различных художественных средств. Рассмотрим наиболее важные концепты.

Цель статьи - исследовать и проанализировать концепт «изобличение» в трагедии «Макбет» путем анализа использованных автором в тексте произведения эпитетов.

С самых первых страниц трагедии перед нами предстает образ доблестного полководца Макбета, родственника короля, бесстрашного воина, почитаемого всеми: народом, придворными и самим королем. Для вербализации концепта «доблесть» У. Шекспир использует эпитеты и вкладывает их в уста множеству действующих лиц.

But all's too weak, for brave Macbeth (well he deserves that name), (SERGEANT)

\section{O valiant cousin! Worthy gentleman! (DUNCAN)}

Norway himself, assisted by that most disloyal traitor the Thane of Cawdor, began a dismal conflict till Macbeth confronted him, point against point, curbing his lavish spirit. (ROSS)[8]

Один из центральных концептов в пьесе «Макбет» У. Шекспира - концепт «предательство» Макбета, его размышлений, сомнений о планируемых им, совершаемых преступлениях. Первое злодейство, на которое решается Макбет - лишение жизни законного короля Дункана, кишит красочными эпитетами в речах самого Макбета.

If good, why do I yield to that suggestion whose horrid image doth unfix my hair and make my seated heart knock at my ribs against the use of nature? (MACBETH)

Stars, hide your fires; let not light see my black and deep desires. (MACBETH)

Besides, this Duncan hath been so clear in his great office, that his virtues will plead like angels, trumpet tongued, against the deep damnation of his taking-off. (MACBETH)[8]

Чудовищность преступления: убийство законного короля Шотландии вложено в речи его приближенных насыщенными эпитетами:

Let us meet, and question this most bloody piece of work, to know it further. (BANQUO)

In the great hand of God I stand, and fight against treasonous malice. (BANQUO)
This murderous shaft that's shot hath not yet lighted, and our safest way is to avoid the aim. (MALCOLM)[8]

Несмотря на тяжесть своего преступления, убийство Дункана и связанных с ним душевных страданий Макбета, он продолжает планировать и совершать злодеяния одно за другим: он нанимает убийц, чтобы расправиться со своим ближайшим другом - Банко и его сыном; расправляется с женой и детьми Макдуфа - сторонника законного наследника Дункана. Стоит отметить, что все последующие рассуждения и преступления нового короля изобилуют художественной составляющей в его речах и мыслях: исчерпывающим наполнением эпитетов.

And with him Fleance his son, that keeps him company, whose absence is no less material to me, must embrace the fate of that dark hour. (MACBETH)

give to the edge of the sword his wife, his babes, and all unfortunate souls that trace him in his line. (MACBETH)

Prophesies have brought forth the most secret man of blood. (MACBETH) [8].

В целом, стоит подчеркнуть достаточную мрачность данного произведения, обилие негативных воплощений и образов в пьесе. Не только сам Макбет со своей супругой Леди Макбет олицетворяют «злое начало» в человеческой природе, но и ведьмы, Геката, обращение к тьме, олицетворение ее, несет в себе концепт»зло», сопровождая его эпитетами.

And, which is worse, all you have done hath been but for a wayward son, spiteful and wrathful, who, as others do, loves for his own ends, not for you. (HECATE)

Round about the cauldron go; in the poisoned entrails throw. (FIRST WITCH) [8]

В трагедии У. Шекспира также присутствуют положительные нравственные концепты, в частности концепты «дружба», «верность долгу», «любовь к родине». Они представлены в речах короля Дункана, его сыновей, знати. Королевский род и приближенные воплощают в себе лучшие человеческие качества, вследствие чего именно через красочность речей придворных У. Шекспир вводит свои нравственные концепты, которые актуализируются с помощью эпитетов для обличения соответствующих собирательных категорий.

Концепт «дружба» проходит через всю трагедию «Макбет». У. Шекспир уделяет ему особое внимание. Уже в начале пьесы еще до предательства Макбета, мы можем видеть, что узы дружбы связывают всех героев: и Макбет и король Шотландии и шотландская знать многократно высказывают «сердечность» своих отношений с помощью эпитетов: 
And the right valiant Banquo walked too late; (LENNOX)

Macduff, this noble passion, child of integrity, hath from my soul wiped the black scruples, reconciled my thoughts to thy good truth and honor. (MALCOLM)

My ever-gentle cousin, welcome hither (MACDUFF) [8]

Злодейства Макбета настолько чудовищны для Шотландии, что властители шотландских областей с болью сердца смотрят на тиранию и деспотию, которую развязал Макбет в их стране, на страдания своего обескровленного и разоренного народа. Представители знати используют многочисленные эпитеты для описания своего «окровавленного» края, своей страдающей Шотландии (концепт «любовь к родине»).

Бесчинства Макбета были настолько беспрецедентными, что шотландская знать поднялась на борьбу против его власти. Макдуф, Росс и другие шотландские таны вместе с законным наследником трона и английским войском отправились освобождать шотландскую землю от правления предателя - Макбета.

When I came hither to transport the tidings, there ran a rumor of many worthy fellows that were out. (ROSS)
But, gentle heavens, front to front bring thou this fiend of Scotland and myself. (MACDUFF) [8]

Концепт «воинская честь» представлен в борьбе за правое дело, за доблесть, честь и достоинство: погибнуть в битве считается достойнейшей смертью, отомстить за смерть жены и детей на поле боя оплотом храбрости и мужества. Все это объективируют эпитеты в устах героев.

\section{Выводы и предложения}

Бесспорно, У. Шекспир является мастером слова, величайшим драматургом своего времени. Его пьесы ставятся во всех странах мира, его язык изучается многочисленными исследователями, его творения восхищают и доставляют удовольствие.

Концепты У. Шекспира объективируются с помощью красочных, образных и насыщенных эпитетов, их многочисленности. Благодаря им мы можем более глубоко постичь воззрения и замысел поэта, его отношение к порочности и добродетельности героев. Также стоит подчеркнуть универсальность шекспировских концептов, их «понятность» для представителей различных народов и культур.

\section{ЛИТЕРАТУРА}

1. Ангелова М.М. «Концепт» в современной лингвокультурологии.[Электронный ресурс]./ М.М. Ангелова. Режим доступа: -https://mgimo.ru/upload/iblock/ 0a4/0a4b1842e5b3a256dd6d6b7a7d6faceb.pdf- 5.10.20.

2. Аскольдов С.А. Концепт и слово. [Электронный ресурс]. / С.А. Аскольдов. Режим доступа: - https://rusneb.ru/catalog/000199_000009_004970449_1142/5.10.20.

3. Гальперин А.И. Очерки по стилистике иностранного языка. - М.: Высшая школа, 2011. - 271с.

4. Гилязаева Э.Н. К вопросу дефиниции эпитета в отечественной и зарубежной лингвистике. [Электронный ресурс]. / Э.Н. Гилязаева. Режим доступа: http://dspace.kpfu.ru/xmlui/viewer?file=128595;spfmpjvtp2017_72_74.pdf\&sequence=-1\&isAllowed=y - 9.10.20.

5. Голуб И.Б. Стилистика русского языка. - М.: Высшая школа, 2010. - 140с.

6. Касьян Л.А. Термин «концепт» в современной лингвистике: различные его толкования. [Электронный ресурс]./ Л.А. Касьян. Режим доступа: - https:// cyberleninka.ru/article/n/termin-kontsept-v-sovremennoy-lingvistike-razlichnye-ego-tolkovaniya/viewer- 5.10.20.

7. Шулястиков И.С. Термин «концепт» в современной лингвистике. [Электронный ресурс]./ И.С. Шулястиков. Режим доступа: -https://cyberleninka.ru/ article/n/termin-kontsept-v-sovremennoy-lingvistike-1 - 5.10.20.

8. Shakespeare W. "Macbeth". [Электронный ресурс]. / W. Shakespeare. Режим доступа: -https://static1.squarespace.com/static/5104656de4b0f96ff4ff9dca/t/5f2 dd3a73fa2e03e47553947/1596838823664/S0L+Macbeth.pdf-1.10.20.

(c) Пирогова Яна Владимировна (yana_pirogova24@mail.ru). 